\title{
Integrating Experiential Learning Into Business Courses: Using Learning Journals To Create Living Case Studies
}

James C. McHann, Walsh College, USA

Laura A. Frost, Walsh College, USA

\begin{abstract}
Research demonstrates that the capacity to implement strategy and to execute plans drives business success (Hrebiniak, 2007) and that businesses' inability to succeed by executing effectively arises from the ubiquitous incapacity of business professionals to overcome the gap between what they know and what they are actually able to do, whether personally or professionally (Pfeffer \& Sutton, 2000). Research and experience also demonstrates that the capacity to execute is not primarily about operational or tactical skills. Rather, it is more a "discipline to learn" (Bossidy, Charan \& Burck, 2002; i.e., the capacity to execute is primarily a discipline of continuously learning to acquire, to interpret, and especially to apply information (Garvin, 2000) in a never-ending spiral of improvement. Business professionals must possess this capacity in order to succeed over the long-term. The purpose of business education is to prepare professionals for successful performance in businesses. However, unlike the preparation of medical doctors and many other professionals, the education in most business schools remains more theoretical than experiential in the andragogy employed. Even the typical case study, like many instructional techniques used in business schools, is still relatively "theoretical" in that it is not a business experience in which the student is personally involved. This paper introduces an instructional method, the journal entry assignment, to help address the challenge of creating a more experiential education and preparation for business. This assignment enables students to "learn by doing" and, in effect, it creates a "living case study" experience for students.
\end{abstract}

Keywords: journal entry assignment, learning journal, case study method, business education, learning, experiential learning, andragogy, instruction, knowing-doing, continuous improvement, PDSA, strategy implementation, execution, mentoring, coaching

\section{THE NEED FOR EXPERIENTIAL LEARNING IN BUSINESS SCHOOLS}

$\mathscr{J}$

he graduates of leading business schools know a lot more than they are able to do. That is the conviction of a growing number of leaders and managers in businesses, government entities, and organizations of all types (Elmuti, 2004). Students learn a great deal in business school, they acquire a lot of knowledge, but most students do not receive much education, training, or skill development in how to put their knowledge into practice in the real world (Chia \& Holt, 2008). That's just not the focus or priority of current business school education; indeed, it appears to be a secondary emphasis or even a mere afterthought in most of the education provided (Navarro, 2008).

Not surprisingly, many graduates evidence an inability to put their knowledge into practice individually, and complex organizations full of such people also demonstrate an even greater incapacity to take what the organization knows to do and actually do it. As Pfeffer and Sutton (1999) point out in the results of their multi-year research study at Stanford Business School, the greatest problems facing most firms is "not the inertia of indifference or ignorance but of knowing too much and doing too little" (p. 135). Pfeffer and Sutton (2000) call this serious and debilitating problem the knowing-doing gap and claim that it exists in many American organizations and that it dramatically affects their competitive success! 
Conscious of this reality, Ram Charan of Harvard and Kellogg (the theorist) teamed up with Larry Bossidy of Honeywell, Allied Signal, and GE (the practitioner) to focus upon the problem of "how to get it done" from the corporate perspective. A careful read of their study (Bossidy, Charan, \& Burck, 2002) reveals that the ability to execute is a discipline to be learned, and it is an important discipline to learn, they would argue, because it makes the ultimate difference between competitors, whether the competitors are individuals or giant corporations.

So when and how is this discipline, i.e., the ability to execute, learned? Is it to be learned only later when the leader or manager is working for an organization, or is it something that aspiring leaders and managers should begin learning in business school? Unfortunately, as the research of Morgan, Lombardo, and Morrison (1988), and a number of others has pointed out, business school students do not really learn this discipline, and much of what they do learn does not really prepare them for their real world profession.

Research at Wharton Business School (Hrebiniak, 2005) has shown that when it comes to organizational strategy, for example, organizations and their executives tend to focus much more of their time, energy, and resources upon the "sexier" stage of strategy, viz., strategy formulation, and neglect to give sufficient attention to the "less sexy" stages of strategy, viz., strategy implementation and evaluation. They do this to their competitive peril, in spite of all the evidence that supports the importance of implementation and evaluation, and in spite of the results of executive surveys that show they clearly understand the import of implementation and evaluation.

Why? Is it because strategy formulation seems more like the research and knowledge development they encountered in business school, i.e., that strategy formulation seems like important knowledge and strategy implementation and evaluation seem like mere practice that should be left to less important underlings, which is what Hrebiniak's (2005) research showed? From where might this mental model have come, or where did they get conditioned to this mental model? Might it have been through their formal educational experience, including in particular their business school education?

If one intertwines a study of the history of philosophy in the West with a study of the history of education in Europe and North America, a pattern emerges that tends to emphasize theory over practice in our education, especially in the life and work of the university. As Raelin (2007) notes in his award-winning article, "Still ensconced in a Cartesian world, we tend to think of theory and practice as separate" (p. 495), and we in academe tend to put a much higher value upon theory. While Raelin's observation is correct, in actuality the problem is not just with rationalism but also with empiricism.

Both of these epistemological approaches battled for domination in Europe during the formative years of the university concept. While the Continentals tended to emphasize rationalism and the Anglo-Saxons tended to emphasize empiricism - and notwithstanding the more recent influences of the diverging epistemologies or hermeneutics inherent in pragmatism, phenomenology, existentialism, and the various historical and process schools - the history of the university in the western world has typically focused upon acquiring new information, formulating and testing theory, and thereby supposedly creating new knowledge, largely in a subject-object bifurcation that has seriously depreciated the learning and knowledge obtainable from practice and dynamic human experience (Betti, 1962; Palmer, 1969; Habermas, 1971; Gadamer, 1975; Mantzavinos, 2008).

As Locke (2002), correctly observes, "Teaching rests on the field of philosophy, and most specifically on epistemology" (p. 195), or alternatively, as Gadamer (1975) would assert, on hermeneutics. The key point here is that the mode of research and the mode of teaching in the business schools of most of our universities have reflected unconsciously, and often uncritically, our philosophical mental models and our professional value system as business school professors. As Nobel laureate F.A. Hayek (1988), whom Drucker called the preeminent social philosopher of our time, would have predicted, we may have operated more unconsciously out of mental models passed on through our inherited tradition, and less out of reasoned purpose than we suppose!

The purpose of the education provided by most business schools is to prepare professionals for successful performance in businesses, government entities, and other organizations. However, unlike the preparation of medical doctors and many other professionals, the education in most business schools remains more theoretical than experiential (Wren, Buckley, \& Michaelsen, 1994). 
Many of the elite university business schools put a higher priority upon research and theory development than upon teaching - faculty prestige and promotion often are driven more by the former than the latter - and when energies are directed toward teaching, the focus is usually upon helping students acquire information or knowledge of a theoretical nature. Traditionally, the amount of experiential and truly practical education provided has been quite limited, and even business school educators frequently acknowledge the preeminence of theory over application in their pedagogy (Wren, Halbesleben, \& Buckley, 2007).

Lower tier business schools often realize they do not have the financial resources or faculty capabilities to compete head-to-head with research-oriented business schools, so they usually respond by promoting themselves as providing a "practical" business education. Using relatively large numbers of low-paid, part-time adjunct faculty, who make their primary living elsewhere, these schools commonly assume that using full-time practitioners as parttime faculty ipso facto results in the delivery of an experiential, practical business education that purposively prepares graduates for effective performance. While these types of faculty often love their avocation and provide copious "war stories" from their day jobs, the mode of teaching they employ is seldom, upon close inspection, very different from their institutions' full-time, professional faculty. In other words, lower tier business schools are not really providing a more practical or application-oriented preparation for the profession than their elite business school counterparts.

At one time, whether at elite or lower tier schools, the professional education typically provided for business was a series of courses where faculty lectured or lead discussions, students read textbooks and articles, and learning was fostered and assessed by research papers, class presentations, and exams. Except for an occasional internship, these theoretical studies were utterly separate from the students' work experience. Either students went to school full-time, graduated, and then found a job where they gained experience, or they worked full-time and took classes part-time, but in both cases learning through study and learning through work tended to be separated experiences.

Imagine for a moment if medical doctors, let's say surgeons, were prepared for their profession in this manner. Assume they studied medical books, did extensive laboratory work, wrote research papers, participated in discussions, passed exams, and maybe had a summer internship that was tangentially connected to the curriculum and haphazardly supervised. Most of us would have less confidence in surgeons prepared like this until they had proven experience. Because the competence of medical school graduates really matters, their professional preparation begins with theoretical studies but aggressively moves more and more toward an integrated, hands-on, mix of theoretical reflection and learning from doing. In the earliest stages, it is more theoretical reflection, in the latter stages it is more reflection upon practice, but throughout the process medical education executes learning by doing more so than business education. As Pfeffer \& Sutton (1999) point out, "In surgery, there is an old saying that describes how residents learn a procedure: 'Hear one, see on, do one.' In business education, the saying would go, 'Hear one, talk about one, talk about one some more"' (p. 137).

Through the years, leading business schools have become more existentially aware of this issue, and they have sought gradually to move business school professional preparation toward a more experientially oriented pedagogy or andragogy (Wren et al., 2007). Unfortunately, systemic structures are in place, which make large scale, institutional moves toward more of a medical school model difficult. However, at the classroom level business schools can more easily develop techniques or methods to foster business learning through more real world experiences, thereby helping students to move from mere acquisition and interpretation of subject matter to the skillful application of knowledge in actual business situations.

For example, years ago Harvard Business School pioneered the case study approach. When Harvard first began using case studies to help students relate the use of management theories and business concepts to real organizational experiences, it seemed like a novel idea, and initially some professors at other schools wondered if HBS was watering down its intellectual or academic rigor. In other words, the method triggered quasi-conscious mental models that valued theory over practice. Today, business schools around the world ubiquitously employ case studies. Indeed, a whole industry has arisen around the R\&D of case studies and around the use of case studies in teaching. Nonetheless, the typical case study, like many instructional techniques used in business schools, is still relatively theoretical in that it is not a business experience in which the student is personally involved. 
As Gentry (1990) and AACSB guidelines point out, teaching tools that do not involve "actual real world contact" cannot be defined as "experiential learning tools" but merely as "surrogates" for experiential learning (p. 13). Therefore, the traditional case study, which we prefer to call a theoretical case study, does not really engage the student in any meaningful action, and therefore the student does not become truly involved in learning by doing. But this is exactly what is necessary for leaders and managers to overcome the knowing-doing gap both personally and professionally! As McCarthy and McCarthy (2006) point out, the traditional case study is just not enough to prepare leaders and managers with the skills they need.

Pfeffer and Sutton (2000) concluded that "one of the most important insights from our research is that knowledge that is actually implemented is much more likely to be acquired from learning by doing than from learning by reading, listening, or even thinking" (pp. 5-6), and they note that "taking action will generate experience from which you can learn" (p. 6). In other words, based upon their research and observations of companies that demonstrated little or no knowing-doing gap, they realized that if you are learning from your own actions and behaviors, then there won't be much of a knowing-doing gap, because you will be "knowing" on the basis of your doing, and implementing that knowledge will be substantially easier" (p. 25).

In addition, as Davenport (1999), Stewart (1999), Choo \& Bontis (2002), Daum (2003), and Wickramasinghe \& Von Lubitz (2007), et al., have pointed out, employees who are "learning by doing" are much more likely to develop the necessary learning skills to function effectively as "knowledge workers" at a time when the commercial enterprises of Europe and North America are seeking to shift gradually from Industrial Age organizations to Knowledge Age organizations in order to make a living in the new global economy.

The traditional case study method of teaching and learning was a big step forward. However, building upon the basic and positive idea of the case study - i.e., relating theory to practice-we may be able to go further toward the experiential learning really needed to prepare business school graduates for their professional experience by using additional tools, techniques, and methods to create hybrid or integrated learning experiences that might best be called living case studies. Journal entries can be one of these tools, techniques, or methods.

We need to lay down first some basic concepts before explaining the best use of this method. In other words, we need a little theory before we focus further on this practice.

\section{KNOWLEDGE, LEARNING, AND DOING}

Since the work of C. S. Pierce, William James, John Dewey, Richard Rorty, et al., a growing tradition in American thought has operated, consciously or unconsciously, upon a theory of knowledge that tests meaning and truth claims by their practical consequences, or by how well they work in the real world of human experience, and that sees the function of thought as guiding the action of humans navigating in their environment. One does not have to assume a commitment to some variety or another of formal philosophical pragmatism, however, to stress the importance of moving from abstract theories of experience to the application in experience of theory, which in turn re-informs both theory and further application. Even a committed ethical deontologist can embrace this need.

A classical philosophical schema saw three stages in the process of understanding or knowing: subtilitas intelligendi, subtilitas explicandi, and subtilitas applicandi. However, in modern times, especially in the philosophical hermeneutics qua theory of knowledge of thinkers like Hans-Georg Gadamer, these stages are seen as inseparably integrated. Indeed, in what is often touted as one of the two or three most important philosophical works of the twentieth century, Gadamer (1975) saw these three stages (comprehension, interpretation, and application) as comprising one unified process.

In another important work, Garvin (2000) summarizes a number of scholarly studies over recent years and across disciplines and viewpoints regarding individual and organizational learning, and he finds that "virtually all studies" (p. 20) divide the learning process into more or less three stages:

1. Acquiring information, i.e., "assembling facts, observations, and data" (p. 20), "separating 'signals' from "noise" (p. 21) to determine the data important to an individual or organization, turning data into 
information, and collecting, organizing, and marshalling knowledge that is available from other sources.

2. Interpreting information, i.e., "producing perspectives, positions, and refined understanding" (p. 20) by connecting or integrating important information in a relevant and meaningful fashion to an individual's or an organization's contextual situation.

3. Applying information, i.e., individuals and organizations use information by "engaging in tasks, activities, and new behaviors" (p. 20) that are intended to achieve the individual's or organization's goals, mission, and vision.

Not surprising, given the well-known research of Chris Argyris and David Schön, and the teaching traditions of Harvard where he works, Garvin makes an extremely important point about the last stage, the stage of application: "Because learning is usually associated with thinking rather than doing, this stage is not always considered to be part of the learning process. But . . . action is essential; if an entity does not purposefully modify its behavior to reflect new knowledge and insights, it does not qualify as a learning [individual or] organization" (p. 26). Earlier in his book, Garvin defined a learning organization carefully and then noted: "According to this definition, learning requires action" (p. 11). This is true of individual learning too.

To the extent this is true, i.e., that "learning requires action," then to that same extent our efforts to help students learn and prepare for their professional careers must find ways to infuse action into their learning. Most of our classes do a good job of helping students acquire information. Some classes even go further and help students interpret information in a relevant, meaningful way to their individual or organizational situation. But few classes focus upon helping them learn to actually apply what they are studying. And yet, we have evidence from business history and experience that a focus upon application can produce amazing learning, improvement, productivity, and success.

Scholtes (1997), perhaps one of Deming's most influential protégés, recounts Dr. Deming's initial visits to Japan at the end of World War II. The Japanese had been humbled by having to "endure the unendurable," viz., defeat and surrender. Unlike the business elite of America, the leaders of Japan opened their minds to Deming's teachings. The cornerstone of all he taught them was compressed in a elegantly simple and profoundly powerful scheme for application -PDSA or "Plan, Do, Study, Act" (pp. 31-34). The Japanese embraced this method of learning by doing in a thoroughgoing and systemic manner within business, government, education, and other aspects of society. As a result, Scholtes (2007) observes, within twenty years they took approximately $50 \%$ of world market share from the United States across a long list of industries.

Representing Deming's philosophy, Scholtes (2007) says that "the proof of a theory is in its successful application," or put another way: "Theory by itself teaches nothing. Application by itself teaches nothing. Learning is the result of dynamic interplay between the two" (p. 32). PDSA exemplifies this interplay. Scholtes (2007) describes Deming's PDSA model for thinking, learning, working, and living: Plan involves development of theory and formulation of strategy. Do involves application of theory and the implementation or execution of strategy. Study involves reflection upon the outcomes of our doing, an assessment of what went right or wrong, and an accruing of insight to guide our next iteration in the process. Act involves a reformulation of our theory, an adjustment of our methods, and correction in our behaviors, leading to a new stage of planning as the cycle or progressive spiral of PDSA continues.

Indeed, Scholtes (2007) says PDSA is a "never-ending cycle of learning and improvement that Deming developed" (p. 33) and taught to the Japanese. One can see this way of learning by doing in the DNA of the Toyota Production System (TPS) (Spear \& Bowen, 1999). PDSA is to TPS what an acorn is to an oak tree. Toyota's capacity to compete by learning can be compared to GM's relative inability to learn and adapt, just as Toyota's preeminence today can be compared to GM's bankruptcy and takeover by the U.S. government. As Pfeffer and Sutton (1999) observe, truly successful organizations like Toyota "make the process of doing into an opportunity to learn" (p. 141). The Deming experience in Japan, along with other poignant lessons from studies in business history, impress upon us again the importance to U.S. business, and to the preparation of the future leaders and managers of American organizations, of learning the habits and techniques for learning by doing. 
When we consider the relationship between the "acquire, interpret, apply" schema for learning taught by Garvin, and the PDSA method that Deming taught the Japanese, we could perceive PDSA as a way to "make the process of doing into an opportunity to learn." The relationship between these approaches can be illustrated in Figure 1 below.

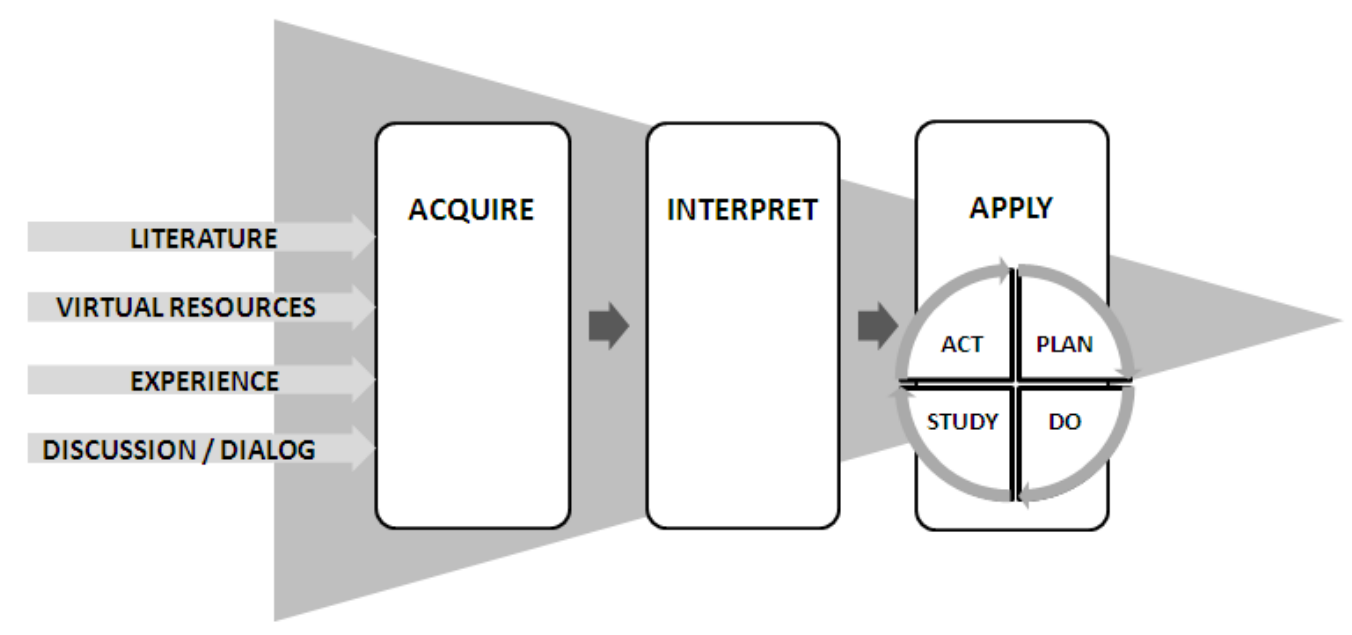

Figure 1: Integration of Learning Models

However, the reflective, iterative, action-oriented, and continuous nature of "acquire, interpret, and apply" (Garvin) and "plan, do, study, act" (Deming) are not easily learned in a typical business school course because the classroom environment's structure tends to militate against the practice of these operations. But since practice is absolutely necessary to develop these skills, how can business school students learn how to engage personally and professionally in learning by doing?

Our argument in this paper is that journaling assignments can help students to practice these learning operations, even while taking business school courses in traditional educational structures.

\section{USING JOURNAL ASSIGNMENTS TO TEACH "APPLICATION" AND "LEARNING BY DOING"}

Given the academic structures of most business school degree programs, traditional instructional tools and methods do a good job with acquisition and interpretation of information, but our classroom toolbox for teaching application by engaging students in learning by doing experiences is more limited.

While journaling as a tool or method of business education has not often been employed in the traditional mix of assignments - e.g., required readings, research papers, traditional theoretical case studies, guided discussions, quizzes and exams - the use of journaling as a tool for reflection, interpretation, plans for action, and growth in personal and professional understanding has ancient and world-wide precedents. Successful leaders down through the ages and around the world have written down their meditations, collated their memoirs, kept diaries, or maintained journals in order to use the process as a tool for learning and improvement. With some methodological development, this tool can be put to powerful use to teach application and inculcate habits of learning by doing.

The current literature on the use of journaling, or journal entry assignments, or "learning journals" is relatively limited, and much of this literature emphasizes journals as only a tool for "reflection," i.e., acquisition and interpretation (Cisero, 2006; Cunliffe, 2004; Ramsey, 2000). While Raelin (2007) documents the scholarly research that emphasizes how extremely valuable methodical reflection or interpretation can be, we propose that the real need educationally is to go even further and use the tool of journaling to traverse all three stages of learning - acquiring information, interpreting information, and especially applying information. In addition, this more ambitious 
approach is supported by the emphasis upon application in modern philosophical hermeneutics, and the manner in which we have used the tool of journaling has in practice strengthened students' skills in application.

Like most business school professors, our classes contain weekly lectures, textbook readings, articles, traditional theoretical case studies, etc., and we consider these valuable inputs as ways to help students acquire the important information they need about the course subject matter. We also engage in weekly guided discussions and other techniques to help students interpret the important information of the course to their personal and professional lives. At the same time, we assign students to write a 1-3 page journal entry each week on some idea, concept, principle, or insight that they have encountered in the course that week, and we stress that the focus of the assignment is report on how they applied or began to apply something from their studies that week to their personal and/or professional lives.

The topic of their journal entry can be anything of their choosing, as long as they can cite, report, or locate the source of the acquired information within the content presented in the course. Syllabi instructions to the students about their journal entry assignments encourage them to strive to use the journal entry assignment to direct their own studies as much as possible toward personal and professional usefulness to themselves. We take this open-ended approach because we want our use of journaling to constitute more of a "pull" versus a "push" approach to business education.

This approach also aligns well with the nature of real application, viz., it is doing, and this doing needs to be done by the student in their real world experience, whether in their own pursuit of "personal mastery" or in their development at work into a more effective leader or manager of others in an organization. Also, we have learned that learning how to apply or learning by doing must be more "self-directed" and "caught" than "taught."

At the same time, the topic chosen by the student must come directly out of the content covered in the course. While the traditional assignments we employ can continue to enable students to acquire information about all the concepts that must be covered by the course, the student's journal entries enable a series of concepts selected by the student to be interpreted and applied, thereby enabling learning by doing. This makes the learning of some of the course subject matter-i.e., the concepts selected by the student-more memorable, meaningful, and useful to the student.

Clear and specific instructions are given about the structure or format of the journal entry, because we have discovered that learning how to write the journal is itself a means of teaching application. The instructions specify that the journal should have four parts:

1. A brief update or accountability report on the progress made on some previous application-per the iterative, cyclical, spiral nature of real experiential learning (e.g., in PDSA)—begun in a previous week and continuing to ripple forward with consequences or developments.

2. A brief summary, usually one paragraph, of the idea, concept, principle, or insight they have selected for this week's journal, which they could leverage in their life or work. This summary should clearly identify from where the topic came in the course materials, and it should reflect an accurate understanding of the content.

3. A slightly longer statement, usually a couple of paragraphs, of how the student interprets the relevance of this topic or unit of content to themselves, their life situation, and/or, ideally, their work situation.

4. An in-depth description of how the student developed a) a plan of action - delineating specific action steps to be taken - in order to apply the content to their personal or professional context, with a focus or preference upon current positive changes that the student can make in their present situation, b) a report on how they actually executed or began to implement their plan, c) an account of the outcomes of putting the plan into action, and d) a brief discussion on how to change things going forward to improve on the results. (Notice that steps $4 \mathrm{a}-4 \mathrm{~d}$ of this application stage of learning follow the PDSA model.)

Also, in the syllabi instructions, the emphasis is that the journal entry is not the real assignment. Instead, students are told that the journal entry is merely their report on the real assignment, which is their application of a concept from the course content to their real life in a way that truly benefits them. They are strongly, and throughout 
the course, repeatedly encouraged to take the journal assignment very seriously, to be brutally honest with themselves, and to do the journal for themselves, not just for a grade. The students are reminded that their real reward is progress toward achieving their personal and professional goals as well as an increased capacity or skill to "learn by doing."

At the beginning of the course, we give students a sample journal entry that is relevant to the subject matter of the course. This sample journal entry serves as a starting model for the students to emulate. In addition, each week we pick out one of the best journals — one that exemplifies the model to follow—and with the student author's permission we either read the journal in class, and then we discuss it, or, if it is an online class, we send an electronic copy to students with some of our feedback attached.

With these examples, students begin to catch on to the journaling format and process quickly, and most importantly, they also begin to evidence a growing capacity to move from acquisition, through interpretation, to ever deeper levels of application. As their efforts at application become more effective, they begin to see positive changes and personally meaningful impacts in their life and career that stimulate even more enthusiasm for engaging in this process during the term of the course and beyond. This learning process becomes a reinforcing or amplifying process that gains momentum with practice.

We also seek to help students learn this skill by our grading and feedback process. The rubric we use for grading reinforces the key steps of the journaling process which thereby becomes a training tool. Figure 2 contains the rubric used in a recent course where ten weekly journals, over an 11-week term, constituted 250 points out of a 1,000 total points for the course:

\begin{tabular}{|c|l|}
\hline Points & Criteria \\
\hline $5 \mathrm{pts}$ & Communication: Logic \& English Composition of Journal Paper \\
\hline $5 \mathrm{pts}$ & Acquire: Accurate Understanding of the Concept Discussed \\
\hline $5 \mathrm{pts}$ & Interpret: Valid \& Relevant to Personal/Professional Situation \\
\hline $5 \mathrm{pts}$ & Apply: A Clear Plan for Execution \\
\hline $5 \mathrm{pts}$ & Apply: Evidence of Specific Action Steps Actually Initiated/Taken \\
\hline $\mathbf{2 5}$ points & Total \\
\hline
\end{tabular}

Figure 2: Rubric used to grade journal entries in an MBA course in management.

However, we have found that the most important means for making this a powerful tool for business education is for the professor to provide thoughtful, written feedback on both the content of the journal entry and persistent guidance on how to improve learning by doing through the use of this tool and its concomitant practices. Therefore, we read each journal entry carefully, whether it is in an onground or an online class, and we provide personalized feedback to each student.

Sometimes this feedback relates to the topic or course content unit addressed in the journal. The journal entry gives surprising insights to the professors about what students understand or misunderstand about the subject matter itself, and this is often an opportunity to correct, amplify, or deepen a student's understandings.

Often, the student has a good understanding of the subject matter, but they have a skewered understanding of how a given concept might validly and relevantly relate to their personal or professional situation. This can be caused by a host of factors that often never appear through normal assignments and assessments, but the journal entry reveals them because the student must try to interpret the content properly.

Most of the time, quite shockingly, students begin with little or no clue as to how to develop a "clear plan for execution" and even less of an ability to "evidence specific action steps actually initiated/taken." Here is where the professor can contribute the most value to the student's education! Indeed, taking advantage of this opportunity to provide helpful feedback about how to apply greatly enhances the effectiveness of the student's business education, it creates a greater connectedness and rapport between the professor and the student, and it gradually turns the professor's efforts into a kind of short-term coaching or mentoring relationship with the student. Actually, 
we have found that long after an eleven-week course is over, many of the students who have taken our classes continue to use this learning tool and maintain appreciative contact with us for years.

Lastly, the use of journal entry assignments is also valuable in demonstrating, for accreditation purposes, how a business program delivers "practical" business education. Many business schools "claim" to deliver a "practical" business education to students, and tell accrediting bodies that they are doing so, but since in reality their teaching methods largely focus upon delivering a theoretical acquisition of subject matter information, documenting the "practical" nature of the program can prove challenging. However, copies of students' journal assignments, of the type discussed in this paper, can provide documentation to accrediting agencies that the institution is indeed striving to provide a "practical" or "applied" business education.

\section{CONCLUSION: LEARNING JOURNALS CAN CREATE "LIVING CASE STUDIES"}

We have argued that business schools can and should integrate more experiential learning into business courses, especially since the purpose of business school education is to prepare graduates for the profession of leading and managing real world organizations. Many of the current teaching tools used to help students move from academic theory to real world practice, e.g., the traditional case study method, are themselves largely "theoretical" in that they do not really engage the students personally or professionally in learning by doing.

Unfortunately, the macro structure of existing business schools makes it very difficult for them to emulate the kind of truly applied education medical schools and some other professional development programs provide their students. Nonetheless, at the classroom level of structure, the use of learning journals can help to create "living case studies" for students. By learning to use journals to acquire, interpret, and apply information from their course work to their actual, real-time, real world lives and work, students do engage in learning by doing. And, indeed, as they traverse all three stages of real learning through the use of this tool, their own lives and work experiences become the living case study in which they learn deeply, existentially, and memorably the content of a given course.

Gradually, as professors use this tool to create more "living case study" experiences, we begin to achieve one of our ultimate goals through the journal assignments, viz., that this method of thinking, learning, living, and working will become a habit used by the student not just in the course, or even throughout their degree program, but for years to come.

\section{AUTHOR INFORMATION}

James C. McHann is a professor of management at Walsh College in Troy, Michigan. He earned a PhD from the University of Aberdeen, Scotland in hermeneutics (the theory of how human beings understand meaning communicated across time, languages and cultures and therefore learn in constantly changing contexts) and an MBA from the Kellogg School of Management at Northwestern University. Dr. McHann has blended these two fields of study, along with over fifteen years of general management experience at the President \& CEO level, into a forte in how individuals and organizations learn and manage change into more positive futures. jmchann@walshcollege.edu

Laura A. Frost is a professor of management at Walsh College in Troy, Michigan, and an active management consultant. She earned a B.S. in mathematics and computer science from Lawrence Technological University, an MBA in operations science from the University of Michigan, and is pursuing doctoral studies in general management at the University of Maryland. Professor Frost brings over twenty-five years of business and academic experience to her present roles as educator and consultant. Her current research is focused upon methods for experiential learning and the transfer of knowledge from the classroom to the workplace. lfrost@walshcollege.edu

\section{REFERENCES}

1. Allee, V. (2003). The future of knowledge. Boston: Butterworth Heinemann.

2. Alm, C. (1996). Using student journals to improve the academic quality of internships. Journal of Education for Business, 72(2), 113.

3. Argyris, C. (1991). Teaching smart people how to learn. Harvard Business Review, 69(3), 99-109. 
4. Argyris, C. (1993). Knowledge for action: A guide to overcoming barriers to organizational change. San Francisco: Jossey-Bass.

5. Argyris, C. (1999). On organizational learning (2nd ed.). Malden, MA: Blackwell Business.

6. Betti, E. (1962). Die hermeneutik als allgemeine methode der geisteswissenschaften. Tubingen: Mohr, 1962. (Hermeneutics as the general methodology of the social sciences.) Translation in Bleicher, J. (1980). Contemporary hermeneutics: Hermeneutics as method, philosophy and critique. London: Routledge and Kegan Paul, 1980, 51-94.

7. Bernstein, R. J. (1983). Beyond objectivism and relativism: Science, hermeneutics, and praxis. Philadelphia: University of Pennsylvania Press.

8. Bickford, D. \& Van Vleck, J. (1997). Reflections on artful teaching. Journal of Management Education, 21(4), 448.

9. Bigelow, J., Seltzer, J., van Buskirk, W., \& Hall, J. (1999). Management skills in action: Four teaching models. Journal of Management Education, 23(4), 355-376.

10. Bossidy, L., Charan, R., \& Burck, C. (2002). Execution: The discipline of getting things done. New York: Crown Business.

11. Boud, D. (2001). Using journal writing to enhance reflective practice. New Directions for Adult and Continuing Education. 90, 9-17.

12. Brown, T., McCracken, M. \& O’Kane, P. (2009). Revisiting transfer through a qualitative analysis of reflective learning journals. Proceedings of the 2009 Academy of Management Annual Meeting. Retrieved from http://www.aomonline.org

13. Burgoyne, J. G. (1994). Managing by learning. Management Learning, 25(1): 35-55.

14. Carson, L, \& Fisher, K. (2006). Raising the bar on criticality: Students' critical reflection in an internship program. Journal of Management Education, 30(5), 700-723.

15. Chia, R., \& Holt, R. (2008). The nature of knowledge in business schools. Academy of Management Learning \& Education, 7(4), 471-486.

16. Choo, C. W., \& Bontis, N. (Eds.) (2002). The strategic management of intellectual capital and organizational knowledge. Oxford: Oxford University Press.

17. Chia, R., \& Morgan, S. (1996). Educating the philosopher manager: De-signing the times. Management Learning, 27(1): 37-64.

18. Cisero, C. A. (2006). Does reflective journal writing improve course performance? College Teaching. 54(2), 231-6.

19. Crossan, M. (2003). Altering theories of learning and action: An interview with Chris Argyris. Academy of Management Executive, 17(2), 40-46.

20. Cunliffe, A. (2004). On becoming a critically reflexive practitioner. Journal of Management Education, 28(4), 407-426.

21. Darling, M., Parry, C., \& Moore, J. (2005). Learning in the thick of it. Harvard Business Review, 83(7/8), 84-92.

22. Daum, J. (2003). Intangible assets and value creation. Hoboken, NJ: Wiley \& Sons.

23. Davenport, T. (1999). Human capital: What it is and why people invest in it. San Francisco: Jossey-Bass Publishers.

24. Dehler, G. \& Edmonds, R. (2006). Using action research to connect practice to learning: A course project for working management students. Journal of Management Education, 30(5), 636-669.

25. Deming, W. (1986). Out of the crisis. Cambridge: Massachusetts Institute of Technology.

26. Deming, W. (2000). The new economics for industry, government, education. MIT: Center for Advanced Engineering Study.

27. Dennehy, R., Ronald R Sims, \& Heather E Collins. (1998). Debriefing experiential learning exercises: A theoretical and practical guide for success. Journal of Management Education, 22(1), 9-25.

28. Drucker, P. (2005). Managing oneself. Harvard Business Review, 83(1), 100-109.

29. Elmuti, E. (2004). Can management be taught? If so, what should management education curricula include and how should the process be approached? Management Decision, 42(3/4), 439-453.

30. Falk, D. (Winter) Preflection: A strategy for enhancing reflection. NSEE Quarterly, 23, 13.

31. Fenwick, T. J. (2001). Responding to journals in a learning process. New Directions for Adult and Continuing Education. 90, 37-47 
32. Gadamer, H.-G. (1975). Truth and Method. (W. Glen-Doepel, Trans.). New York: Seabury Press. (Original work Wahrheit und Methode: Grundzuge einer philosophischen Hermeneutik, 1960).

33. Garvin, D. (2000). Learning in action: A guide to putting the learning organization to work. Boston: Harvard Business School Press.

34. Garvin, D. (2007). Teaching executives and teaching MBAs: Reflections on the case method. Academy of Management Learning \& Education, 6(3), 364-374.

35. Gentry, James W. (1990). What is experiential learning? Guide to business gaming and experiential learning. (pp. 9-20) Association for Business Simulation and Experiential Learning.

36. Govekar, M., \& Rishi, M. (2007). Service learning: Bringing real-world education into the B-School classroom. Journal of Education for Business, 83(1), 3-10.

37. Habermas, J. (1971). Knowledge and human interests. (J. J. Shapiro, Trans.), Boston: Beacon Press.

38. Habermas, J. (1984). The theory of communicative action. Vol. 1: Reason and the rationalization of society. (T. McCarthy,Trans.). Boston: Beacon Press.

39. Hayek, F. (1988). The fatal conceit. (W.W. Bartley III, Ed.). Chicago: The University of Chicago Press.

40. Hess, P. (2007). Enhancing leadership skill development by creating practice/feedback opportunities in the classroom. Journal of Management Education, 31(2), 195-213.

41. Hrebiniak, L. (2005). Making strategy work: Leading effective execution and change. Philadelphia: Wharton School Publishing.

42. King Jr., W. (1998). A semester-long experiential exercise to develop workplace understanding: The role assignment exercise. Journal of Management Education, 22(6), 720-735.

43. Knights, D. 1992. Changing spaces: The disruptive impact of a new epistemological location for the study of management. Academy of Management Review, 17, 514-536.

44. Kuhn, D., Amsel, E., \& O’Loughlin, M. (1988). The development of scientific thinking skills. San Diego, CA: Academic Press.

45. Larsen, H. (2004). Experiential learning as management development: Theoretical perspectives and empirical illustrations. Advances in Developing Human Resources, 6(4), 486-503.

46. Lederman, L. C. (1992). Debriefing: toward a systematic assessment of theory and practice. Simulation \& Gaming, 23(2), 145-161.

47. Lee, A. S. (1991). Integrating positivist and interpretive approaches to organizational behavior. Organization Science, 2, 342-365.

48. Li, T., Greenberg, B., \& Nicholls, J. (2007). Teaching experiential learning: Adoption of an innovative course in an MBA marketing curriculum. Journal of Marketing Education, 29(1), 25-33.

49. Locke, E. (2002). The epistemological side of teaching management: Teaching through principles. Academy of Management Learning \& Education, 1(2), 195-20.

50. Locke, K., \& Brazelton, J. (1997). Why do we ask them to write, or whose writing is it, anyway?" Journal of Management Education, 21(1), 44-57.

51. Mantzavinos, C. (2008). Naturalistic hermeneutics. Cambridge: Cambridge University Press.

52. McCarthy, P., and McCarthy, H. (2006). When case studies are not enough: integrating Experiential Learning into Business Curricula. The Journal of Education for Business, 81(4), 201-204.

53. McDermid, D. Pragmatism, Internet Encyclopedia of Philosophy, Last updated on December 15, 2006, found at http://www.iep.utm.edu/pragmati/ on 9/28/09.

54. Morgan, W., Lombardo, M., \& Morrison, A. (1988). The lessons of experience. Lexington, MA: Lexington Books.

55. Navarro, P. (2008). The MBA core curricula of top-ranked U.S. business schools: A study in failure? Academy of Management Learning \& Education, 7(1), 108-123.

56. Palmer, R. (1969). Hermeneutics. Evanston: Northwestern University Press.

57. Petranek, C. (2000). Written debriefing: the next vital step in learning with simulations. Simulation \& Gaming, 31(1), 108-119.

58. Pfeffer, J., \& Fong, C. (2002). The end of business schools? Less success than meets the eye. Academy of Management Learning \& Education, 1(1), 78-95.

59. Pfeffer, J. \& Sutton, R. (2000). The knowing-doing gap: How smart companies turn knowledge into action. Boston: Harvard Business School Press.

60. Pfeffer, J., \& Sutton, R. (1999). The smart-talk trap. Harvard Business Review, 77(3), 134-142. 
61. Polkinghorne, D. (1983). Methodology for the human sciences: Systems of inquiry. Albany: State University of New York Press.

62. Raelin, J. (2007). Toward an epistemology of practice. Academy of Management Learning \& Education, 6(4), 495-519.

63. Raelin, J. \& Coghlan, D. (2006). Developing managers as learners and researchers: using action learning and action research. Journal of Management Education, 30(5), 670-689.

64. Ramsey, V. J. (2002). Learning journals and learning communities. Journal of Management Education, 26(4), 380.

65. Scholtes, P. (1997). The leader's handbook: Making things happen, getting things done. New York: McGraw-Hill.

66. Simmonds, P., Dawley, D., Ritchie, W., \& Anthony, W. (2001). An exploratory examination of the knowledge transfer of strategic management concepts from the academic environment to practicing managers. Journal of Managerial Issues, 13(3), 360.

67. Spear, S., \& Bowen, H. (1999). Decoding the DNA of the Toyota Production System. Harvard Business Review, 77(5), 96-106. http://proxy01.academic.walshcollege.edu:2068

68. Stacey, R. (2001). Complex responsive processes in organizations: Learning and knowledge creation. New York: Routledge.

69. Stewart, T. (1999). Intellectual capital: The new wealth of organizations. New York: Currency/Doubleday.

70. Tsoukas, H. (2005). Complex knowledge: Studies in organizational epistemology. New York: Oxford University Press.

71. Tsoukas, H., \& Vladimirou, E. (2001). What is organizational knowledge? Journal of Management Studies, 38(7): 973-993.

72. Van de Ven, A. H., \& Johnson, P. E. (2006). Knowledge for theory and practice. Academy of Management Review, 31(4): 802-821.

73. Varner, D. \& Peck, S. (2003). Learning from learning journals: The benefits and challenges of using learning journal assignments. Journal of Management Education, 27(1), 52.

74. Wickramasinghe, N., \& Von Lubitz, D. (2007). Knowledge-based enterprise: Theories and Fundamentals. Hershey, PA: Idea Group Publishing.

75. Wren, D., Buckley, M., \& Michaelsen, L. (1994). The theory/applications balance in management pedagogy: Where do we stand? Journal of Management, 20(1), 141.

76. Wren, D., Halbesleben, J., \& Buckley, M. (2007). The theory-application balance in management pedagogy: A longitudinal update. Academy of Management Learning \& Education, 6(4), 484-492.

77. Zubizarreta, J. (2004). The learning portfolio: Reflective practice for improving student learning. Bolton, MA: Anker. 